\title{
Temperature and risk factors for ischaemic heart disease in the Caerphilly prospective study
}

Peter C Elwood, Andrew Beswick, John R O'Brien, Serge Renaud, Richard Fifield, Elizabeth S Limb, David Bainton

\begin{abstract}
Objective-To examine the associations between air temperature and risk factors for ischaemic heart disease.

Method-Data on risk factors are available from up to 2036 men in the Caerphilly Prospective Heart Disease Study. Daily temperatures were obtained from the Meteorological Office. Relations between these were examined by regression.

Results-The coldest month of the year has a mean temperature that is $16^{\circ} \mathrm{C}$ lower than that in the warmest month. A fall in temperature of this magnitude is associated with higher blood pressures (by 3-5 mm $\mathrm{Hg}$ ) and a lower concentration of high density lipoprotein cholesterol (by $0.08 \mathrm{mmol} / \mathrm{h}$ ). The most important effects however, seem to be on the haemostatic system. Fibrinogen is $0.34 \mathrm{~g} / 1$ higher in the coldest month than in the warmest $(p<0.001)$ and $\alpha_{2}$ macroglobulin, a protein that inhibits fibrinolysis, is also raised. Platelet count is increased by $30 \%$ of a standard deviation and the sensitivity of platelets in whole blood to adenosine diphosphate is increased by cold.
\end{abstract}

Conclusions-These effects on haemostasis, together with the effect on blood pressure, could explain a large part of the increase in ischaemic heart disease in the winter but are unlikely to explain much of the difference in mortality within different areas of England and Wales.

(Br Heart $\mathcal{f} 1993 ; 70: 520-523)$

Central Laboratory, St Mary's Hospital,

Portsmouth

J R O'Brien

INSERM, Unité 63, 69675 Bron, France

$S$ Renaud

Cardiff Royal

Infirmary, Cardiff,

South Glamorgan

R Fifield

University of Wales College of Medicine, Heath Park, Cardiff, South Glamorgan

D Bainton

Correspondence to: Dr P C Elwood, MRC Epidemiology Unit, Llandough Hospital, Penarth, South Glamorgan CF64 2XW.

Accepted for publication 11 May 1993 is truly cardiovascular is uncertain. Some have suggested that the effect of temperature ischaemic heart disease and related mortality is on respiratory disease and the apparent excess in cardiovascular deaths in winter is simply due to miscoding of the cause of death. ${ }^{7}$ Bainton et al showed that the proportionate increase in deaths was similar in both young and old patients, leading them to conclude that the effect of temperature on the cardiovascular system is direct. ${ }^{8}$ On the other hand, Mackenbach et al, who examined the seasonal pattern of deaths in The Netherlands over nine years, suggest that there is both an instantaneous effect of winter on the cardiovascular system, and a delayed effect mediated by respiratory infections. ${ }^{9}$

In this report we examine the associations between ambient air temperature and a range of risk factors for ischaemic heart disease, including blood pressure, lipids, platelets, and other factors related to thrombosis.

\section{Patients and methods}

The Caerphilly study is fully described elsewhere. ${ }^{1011}$ It is based on a large cohort of men in South Wales. Each man was first seen at an afternoon or evening clinic at which blood pressure was recorded on a random zero muddler sphygmomanometer. Men were then seen at early morning clinics (about 0600 to 1000) after an overnight fast and venous blood was taken without stasis. The order in which blood was taken for the various tests, the handling of the blood samples, and the methodology of the various tests, was rigidly standardised throughout, and each test was done in a single laboratory.

The data we present here were collected on several days each week over the course of more than six years. They come from two phases of the study which, although separate in time, were essentially identical. In the first, the men were aged 50-65 years and all the men in the cohort were seen. Data were collected on blood pressure, plasma lipids, $\alpha_{2}$ macroglobulin, fibrinogen, plasma viscosity, white cell count, and the aggregation of platelets in platelet rich plasma to adenosine diphosphate, thrombin, and collagen. Five years later around 1000 of the men were seen again and a range of haemostatic factors measured-namely: von Willebrand factor, aggregation of platelets in whole blood to adenosine diphosphate by an impedance method, platelet retention in a shear stress activation test, and a skin bleeding time. Technical details of these tests have been given elsewhere. ${ }^{11} 12-14$ 
Table 1 Summary of statistics for the various tests

\begin{tabular}{|c|c|c|}
\hline Test & $\operatorname{Men}(\mathrm{No})$ & Mean (SD) \\
\hline $\begin{array}{l}\text { Blood pressure: } \\
\text { Systolic }(\mathrm{mm} \mathrm{Hg}) \\
\text { Diastolic }(\mathrm{mm} \mathrm{Hg})\end{array}$ & $\begin{array}{l}2366 \\
2366\end{array}$ & $\begin{array}{r}146(22 \cdot 7) \\
85(12 \cdot 2)\end{array}$ \\
\hline $\begin{array}{l}\text { Lipids: } \\
\text { Total cholesterol (mmol/l) } \\
\text { HDL cholesterol }(\mathrm{mmol} / \mathrm{l}) \\
\text { Triglycerides }(\mathrm{mmol} / \mathrm{l})\end{array}$ & $\begin{array}{l}2302 \\
2302 \\
2302\end{array}$ & $\begin{array}{l}5.63(1.02) \\
1.02(0.25) \\
1.98(1.43)\end{array}$ \\
\hline $\begin{array}{l}\text { Haemostatic factors: } \\
\text { Fibrinogen }(\mathrm{g} / \mathrm{l}) \\
\text { Von Willebrand factor }(\% \text { of standard) } \\
\alpha_{2} \text { Macroglobulin }(\mathrm{g} / \mathrm{l}) \\
\text { Plasma viscosity }(\mathrm{cP}) \\
\text { White cell count }\left(\times 10^{9} / 1\right)\end{array}$ & $\begin{array}{r}2278 \\
514 \\
2056 \\
2281 \\
2282\end{array}$ & $\begin{array}{c}3.98(0.89) \\
119(41.1) \\
1.58(0.39) \\
1.677(0.095) \\
6.71(1.99)\end{array}$ \\
\hline $\begin{array}{l}\text { Platelet parameters: } \\
\text { Platelet count }\left(\times 10^{9} / 1\right) \\
\text { Mean platelet volume }(\mathrm{fl})\end{array}$ & $\begin{array}{r}1001 \\
994\end{array}$ & $\begin{array}{l}233(53.9) \\
7.75(0.93)\end{array}$ \\
\hline $\begin{array}{l}\text { Platelet aggregation }{ }^{\star} \\
\text { In PRP, to ADP (primary) (\% PPP) } \\
\text { In PRP, to ADP (secondary) (\% high) } \\
\text { In PRP, to thrombin (\% PPP) } \\
\text { In PRP, to collagen (\% high) } \\
\text { In whole blood, to ADP (mmol/l)† } \\
\text { Retention in filter ( } \% \text { platelets) }\end{array}$ & $\begin{array}{r}1809 \\
1809 \\
1812 \\
1774 \\
1022 \\
937\end{array}$ & $\begin{array}{l}25(8) \\
14 \cdot 2- \\
10(6) \\
41 \cdot 8- \\
1 \cdot 19- \\
65 \cdot 2(16 \cdot 9)\end{array}$ \\
\hline Bleeding time (s) & 759 & $333(119 \cdot 6)$ \\
\hline
\end{tabular}

*For two of the tests in PRP, the optical density after aggregation is shown as a proportion of the optical density of (PPP). For the other tests the proportion of men with a high response is shown (see text).

tThe figure shown for whole blood aggregation is the dose of ADP needed to achieve a 1.5 ohm change in impedance The data for this test have been log transformed throughout and the $95 \%$ range is $0.25-5.69 \mathrm{mmol} / \mathrm{ADP}$, adenosine diphosphate, $\mathrm{PPP}$, platelet poor plasma; PRP, platelet rich plasma. the proportion of men showing a high response to these agonists (as defined elsewhere $\left.^{14}\right)$.

\section{Results}

Table 1 summarises the data available for each test. Numbers for a few of the haemostatic tests are limited because opportunity for their inclusion in the study only arose after the examinations of the men had started.

Table 2 shows the mean results of the nonhaemostatic tests at various daily temperatures. In table 3 the haemostatic tests are displayed in the same way. The selection of temperatures used for the grouping of the data in these tables is of relevance to their interpretation. Over the six years of the study, on average there were 20 days each year on which the temperature at 0800 hours was below $0^{\circ} \mathrm{C}$, on 65 days it was between 0 and $5^{\circ} \mathrm{C}$, and on 112 days each year it was between $5 \cdot 1$ and $10^{\circ} \mathrm{C}$.

The evaluation of trends, however, is best judged from an overall regression analysis to which all the data contribute. Furthermore, the interpretation of such a regression is facilitated by examining changes in the risk factors for a defined temperature change. We have used $16^{\circ} \mathrm{C}$ as this is the difference between the average temperature during the warmest month and the coldest month each year. The evaluation of each of these changes in the risk factors has been further assisted by expressing them as a percentage of the standard deviation for the risk factor.

Table 4 shows that blood pressures are higher in cold temperatures, a $16^{\circ} \mathrm{C}$ fall being associated with a rise of $3-5 \mathrm{~mm} \mathrm{Hg}$, equivalent to about a quarter of a standard deviation of the population distribution of blood pressures. High density lipoprotein cholesterol was lower in cold weather, a $16^{\circ} \mathrm{C}$ fall being associated with a lowering of $0.08 \mathrm{mmol} / \mathrm{l}$, or about one third of a standard deviation.

The data for a number of the haemostatic tests suggest that cold enhances haemostasis. A $16^{\circ} \mathrm{C}$ fall is associated with a rise in fibrinogen of $0.34 \mathrm{~g} / \mathrm{l}$, or just over one third of a standard deviation. $\alpha_{2}$ Macroglobulin shows an increase of about the same size relative to its standard deviation. Other changes associated with a $16^{\circ} \mathrm{C}$ fall include platelet count, which is higher by almost one third of a standard deviation. The evidence on platelet response to aggregating agents is inconsistent in that the response in platelet rich plasma is

Table 2 Mean results of non-haemostatic tests subdivided by ground air temperature on the day of test

\begin{tabular}{|c|c|c|c|c|c|c|c|}
\hline Test & $<0^{\circ} \mathrm{C}$ & $0-5^{\circ} \mathrm{C}$ & $5 \cdot 1-10^{\circ} \mathrm{C}$ & $10 \cdot 1-15^{\circ} \mathrm{C}$ & $15 \cdot 1-20^{\circ} \mathrm{C}$ & $20 \cdot 1-25^{\circ} \mathrm{C}$ & p Value \\
\hline $\begin{array}{l}\text { Blood pressure: } \\
\text { Systolic }(\mathrm{mm} \mathrm{Hg}) \\
\text { Diastolic }(\mathrm{mm} \mathrm{Hg})\end{array}$ & $\begin{array}{r}152 \\
89\end{array}$ & $\begin{array}{r}149 \\
85\end{array}$ & $\begin{array}{r}147 \\
85\end{array}$ & $\begin{array}{r}145 \\
85\end{array}$ & $\begin{array}{r}146 \\
84\end{array}$ & $\begin{array}{r}139 \\
78\end{array}$ & $\begin{array}{l}<0.001 \\
<0.01\end{array}$ \\
\hline $\begin{array}{l}\text { Lipids: } \\
\text { Total cholesterol (mmol/1) } \\
\text { HDL cholesterol (mmol/l) } \\
\text { Triglycerides (mmol/) }\end{array}$ & $\begin{array}{l}5.56 \\
0.96 \\
1.95\end{array}$ & $\begin{array}{l}5.73 \\
0.99 \\
1.98\end{array}$ & $\begin{array}{l}5.62 \\
1.02 \\
1.97\end{array}$ & $\begin{array}{l}5.67 \\
1.04 \\
2.01\end{array}$ & $\begin{array}{l}5.48 \\
1.07 \\
1.99\end{array}$ & $\overline{-}$ & $\begin{array}{l}\text { NS } \\
<0 \cdot 001 \\
\text { NS }\end{array}$ \\
\hline
\end{tabular}

For blood pressure the average daily temperature has been used, for the lipids the temperature used was that at 0800 . 
Table 3 Mean results of haemostatic tests subdivided by ground air temperature at 0800 on the day of the test

\begin{tabular}{|c|c|c|c|c|c|c|}
\hline Test & $<0^{\circ} \mathrm{C}$ & $0-5^{\circ} \mathrm{C}$ & $5 \cdot 1-10^{\circ} \mathrm{C}$ & $10 \cdot 1-15^{\circ} \mathrm{C}$ & $15 \cdot 1-20^{\circ} \mathrm{C}$ & p Value \\
\hline $\begin{array}{l}\text { Haemostatic factors: } \\
\text { Fibrinogen }(\mathrm{g} / \mathrm{l}) \\
\text { Von Willebrand factor }(\% \text { standard }) \\
\alpha_{2} \text { Macroglobulin }(\mathrm{g} / \mathrm{l}) \\
\text { Plasma viscosity }(\mathrm{PP}) \\
\text { White cell count }\left(\times 10^{\circ} / 1\right)\end{array}$ & $\begin{array}{c}4.11 \\
111 \\
1.64 \\
1.683 \\
6.47\end{array}$ & $\begin{array}{c}4 \cdot 12 \\
115 \\
1.61 \\
1.682 \\
6.72\end{array}$ & $\begin{array}{c}4.03 \\
121 \\
1.57 \\
1.674 \\
6.74\end{array}$ & $\begin{array}{c}3.84 \\
118 \\
1.57 \\
1.678 \\
6.73\end{array}$ & $\begin{array}{c}3.93 \\
103 \\
1.48 \\
1.674 \\
6.67\end{array}$ & $\begin{array}{l}<0.001 \\
\text { NS } \\
<0.001 \\
\text { NS } \\
\text { NS }\end{array}$ \\
\hline $\begin{array}{l}\text { Platelet variables: } \\
\text { Platelet count }\left(\times 10^{9} / 1\right) \\
\text { Mean platelet volume }(\mathrm{fl})\end{array}$ & $\begin{array}{r}228 \\
7 \cdot 8\end{array}$ & $\begin{array}{l}238 \\
7 \cdot 7\end{array}$ & $\begin{array}{r}235 \\
7 \cdot 9\end{array}$ & $\begin{array}{l}233 \\
7 \cdot 7\end{array}$ & $\begin{array}{l}216 \\
7 \cdot 7\end{array}$ & $\begin{array}{l}<0.01 \\
\text { NS }\end{array}$ \\
\hline $\begin{array}{l}\text { Platelet aggregation: } \\
\text { In PRP, to ADP (primary) (\% PPP) } \\
\text { In PRP, to ADP (secondary) (\% high) } \\
\text { In PRP, to thrombin (\% PPP) } \\
\text { In PRP, to collagen (\% high) } \\
\text { In whole blood, to ADP (mmol/l) } \\
\text { Retention in filter (\% platelets) }\end{array}$ & $\begin{array}{l}25 \\
10 \cdot 1 \\
9 \cdot 5 \\
33 \cdot 3 \\
0 \cdot 76 \\
63 \cdot 0\end{array}$ & $\begin{array}{l}26 \\
16 \cdot 7 \\
10 \cdot 1 \\
35 \cdot 6 \\
1 \cdot 18 \\
65 \cdot 1\end{array}$ & $\begin{array}{l}25 \\
13 \cdot 8 \\
10 \cdot 2 \\
41 \cdot 0 \\
1 \cdot 15 \\
64 \cdot 2\end{array}$ & $\begin{array}{l}26 \\
14 \cdot 8 \\
10 \cdot 9 \\
46 \cdot 6 \\
1 \cdot 23 \\
65 \cdot 7\end{array}$ & $\begin{array}{l}23 \\
11 \cdot 9 \\
10 \cdot 4 \\
46 \cdot 5 \\
1 \cdot 34 \\
67 \cdot 5\end{array}$ & $\begin{array}{l}\text { NS } \\
\text { NS } \\
<0.001 \\
<0.001 \\
<0.01 \\
\text { NS }\end{array}$ \\
\hline Bleeding time (s) & 314 & 332 & 329 & 339 & 338 & NS \\
\hline
\end{tabular}

Abbreviations as for table 1 .

reduced at the lower temperature to both thrombin and collagen, whereas the sensitivity of platelets in whole blood to adenosine diphosphate is increased. In this last test the dose of adenosine diphosphate required for the defined change in impedance (aggregation) is reduced from 1.34 to $0.76 \mathrm{mmol} / 1$ with a fall of $16^{\circ} \mathrm{C}$.

\section{Discussion}

There are two approaches to the examination of changes in factors over time. Either a group of subjects can be examined repeatedly, or representative subsamples of subjects can be examined at intervals. Stout and Crawford chose to examine temperature and risk factors for ischaemic heart disease with the first approach ${ }^{15}$; we have used the second, using the on going examinations of a large cohort of men to cover a substantial period of time. Although we cannot have absolute certainty that the subsamples of men we saw on the different days are comparable, we know

Table 4 Effect of a $16^{\circ} \mathrm{C}$ difference in ground air temperature on various risk factors for ischaemic heart disease, corrected for age.

\begin{tabular}{|c|c|c|c|}
\hline Test & Absolute & $(\%$ of $S D)$ & p Value \\
\hline $\begin{array}{l}\text { Blood pressure: } \\
\text { Systolic }(\mathrm{mm} \mathrm{Hg}) \\
\text { Diastolic }(\mathbf{m m ~ H g})\end{array}$ & $\begin{array}{l}+5 \\
+3\end{array}$ & $\begin{array}{l}(+22) \\
(+25)\end{array}$ & $\begin{array}{l}<0.001 \\
<0.01\end{array}$ \\
\hline $\begin{array}{l}\text { Lipids: } \\
\text { Total cholesterol }(\mathrm{mmol} / \mathrm{l}) \\
\text { HDL cholesterol }(\mathrm{mmol} / \mathrm{l}) \\
\text { Triglycerides }(\mathrm{mmol} / \mathrm{l})\end{array}$ & $\begin{array}{l}+0.11 \\
-0.08 \\
-0.06\end{array}$ & $\begin{array}{l}(+11) \\
(-32) \\
(-4)\end{array}$ & $\begin{array}{l}\text { NS } \\
<0 \cdot 001 \\
\text { NS }\end{array}$ \\
\hline $\begin{array}{l}\text { Haemostatic factors: } \\
\text { Fibrinogen }(\mathrm{g} / \mathrm{l}) \\
\text { Von Willebrand factor (\% standard) } \\
\alpha_{2} \text { Macroglobulin }(\mathrm{g} / \mathrm{l}) \\
\text { Plasma viscosity }(\mathrm{CP}) \\
\text { White cell count }\left(\times 10^{\circ} / 1\right)\end{array}$ & $\begin{array}{l}+0.34 \\
-0.64 \\
+0.11 \\
+0.009 \\
-0.12\end{array}$ & $\begin{array}{l}(+38) \\
(-2) \\
(+28) \\
(+9) \\
(-6)\end{array}$ & $\begin{array}{l}<0.001 \\
\text { NS } \\
<0 \cdot 001 \\
\text { NS } \\
\text { NS }\end{array}$ \\
\hline $\begin{array}{l}\text { Platelet variables: } \\
\text { Platelet count }\left(\times 10^{\%} / 1\right) \\
\text { Mean platelet volume }(\mathrm{fl})\end{array}$ & $\begin{array}{l}+16 \\
-0.01\end{array}$ & $\begin{array}{l}(+30) \\
(-1)\end{array}$ & $\begin{array}{l}<0.01 \\
\text { NS }\end{array}$ \\
\hline $\begin{array}{l}\text { Platelet aggregation: } \\
\text { In PRP, to ADP (primary) (\% PPP) } \\
\text { In PRP, to ADP (secondary) (\% high) } \\
\text { In PRP, to thrombin (\% PPP) } \\
\text { In PRP, to collagen (\% high) } \\
\text { In whole blood, to ADP (mmol } / 1) \\
\text { Retention in filter (\% platelets) }\end{array}$ & $\begin{array}{l}+0.9 \\
-2 \star \\
-1 \cdot 0 \\
-14^{\star} \\
-0.29 \\
-2 \cdot 4\end{array}$ & $\begin{array}{l}(+11) \\
(-17) \\
(-28) \\
(-14)\end{array}$ & $\begin{array}{l}\text { NS } \\
\text { NS } \\
<0.001 \\
<0.001 \\
<0.01 \\
\text { NS }\end{array}$ \\
\hline Bleeding time (s) & -2 & $(-2)$ & NS \\
\hline
\end{tabular}

`Based on data grouped by temperature.

Abbreviations as for table 1 . of no way in which differences could have introduced bias in the estimation of the effects we describe.

A positive effect of cold on blood pressure has been described repeatedly ${ }^{516}$ and our data confirm that the effect is sizeable, pressures being on average $3-5 \mathrm{~mm} \mathrm{Hg}$ higher in the coldest month compared to the warmest. These effects represent around one quarter of a standard deviation of the distribution of pressures.

An effect on lipids is less certain. Stout and Crawford found no effect on cholesterol or triglycerides, but their data show a small rise in high density lipoprotein cholesterol in the colder months of the year. ${ }^{15}$ By contrast, we find a significant reduction in high density lipoprotein cholesterol, equivalent to about one third of a standard deviation with a $16^{\circ} \mathrm{C}$ fall in temperature.

Interest in effects of temperature on cardiovascular disease now seems, however, to focus on haemostasis. Tromp reported an association between season and fibrinogen, and was perhaps the first to draw attention to thrombosis. ${ }^{17}$ Keatinge et al exposed four male and four female students to cold for six hours and reported significant increases in platelet count, neutrophil count, and plasma and whole blood viscosity..$^{18}$ Our data extend these findings considerably.

We confirm an increase in platelet count at lower temperatures. No change is shown in platelet volume, a measure that has been shown to be predictive of death after a myocardial infarct. ${ }^{19}$ Our data on platelet aggregation seem to be inconsistent, low temperatures being associated with a significant increase in the sensitivity of platelets to adenosine diphosphate when measured in the whole blood test, but not when measured in platelet rich plasma. Aggregation has, however, been shown to be positively dependent on platelet count, ${ }^{20}$ and the standardising of platelet numbers in the tests done with platelet rich plasma (to 300000 platelets $/ \mathrm{ml}$ of plasma in our tests) may reduce the likelihood of any true effect of temperature on the platelets being detected with our platelet rich plasma tests. 
The most striking effect of cold, however, seems to be on plasma fibrinogen concentration. Unfortunately it is difficult to compare our data with those of Stout and Crawford. ${ }^{15}$ These authors give data for two winters but only one summer, and compared with the lowest monthly level in the summer their mean fibrinogen is higher by about $70 \%$ of a standard deviation in the coldest month of the first winter and by $35 \%$ of a standard deviation in the second winter. The monthly effect we describe is about $38 \%$ of a standard deviation.

The relevance of fibrinogen as an important risk factor, predictive of ischaemic heart disease, has been fairly well worked out. ${ }^{121}$ Within this same Caerphilly cohort of men we have described a substantial effect of cigarette smoking on fibrinogen concentrationsnamely, a rise of about $0.65 \mathrm{~g} / 1 .{ }^{22}$ The effect of temperature seems to be about half of this smoking effect, namely a difference of 0.34 $\mathrm{g} / \mathrm{l}$ between the warmest and the coldest months. Current smokers within the cohort have shown a 2.5 excess risk of an ischaemic heart disease event, compared with men who had never smoked, ${ }^{12}$ and we have argued that an important part of this excess is likely to be mediated by effects on haemostatic factors, including fibrinogen. ${ }^{22}$

In conclusion an enhancement of the mechanisms of thrombosis by cold could account for a large part of the winter excess in the incidence of and the mortality from ischaemic heart disease. Our data do not, however, give much support to the suggestion that differences in environmental temperatures might explain the 2:1 range in mortality from ischaemic heart disease in different areas within England and Wales. ${ }^{6}$ The range of annual temperatures is less than $3^{\circ} \mathrm{C}$ and our data indicate that temperature differences of such a size is likely to have only a trivial effect on fibrinogen (about $0.06 \mathrm{~g} / 1$ or $7 \%$ of the standard deviation), and an even smaller effect on blood pressure.

We thank Mr M R Woodley and Mr B Oatway at the Meteorological Office, Bracknell, for the temperature data.

1 Rose G. Cold weather and ischaemic heart disease. British fournal of Preventive and Social Medicine 1966;20: 97-100.
2 Bull GM. Meteorological correlates with myocardial and cerebral infarction and respiratory disease. British fournal of Preventive and Social Medicine 1973;27: 108-13.

3 Deaths in winter. Lancet 1985;ii:987-8.

4 Gyllerup S, Lanke J, Lindholm LH, Schersten B. High coronary mortality in cold regions of Sweden. $f$ Intern Med 1991;230:479-85.

5 Rose G. Seasonal variation in blood pressure in man. Nature 1961;189:235.

6 West RR, Lowe CR. Mortality from ischaemic heart disease-inter-town variation and its association with climate in England and Wales. Int $\mathcal{f}$ Epidemiol 1976;5:195-201

7 Anderson TW, Le Riche WH. Cold weather and myocardial infarction. Lancet 1970;1:291-6.

8 Bainton D, Moore F, Sweetnam P. Temperature and deaths from ischaemic heart disease. British fournal of Preventive and Social Medicine 1977;31:49-53.

9 Mackenbach JP, Kunst AE, Looman CWN. Seasonal variation in mortality in The Netherlands. $\mathcal{f}$ Epidemiol Community Health 1992;46:261-5.

10 Caerphilly and Speedwell Collaborative Group. Caerphilly and Speedwell collaborative heart disease studies. 7 Epidemiol Community Health 1984;38:259-62.

11 Medical Research Council Epidemiology Unit. The Caerphilly Collaborative Heart Disease Studies: project description and manual of operations. MRC Epidemiology Unit Cardiff 1985.

12 Yarnell JWG, Baker IA, Sweetnam PM, Bainton D, O'Brien JR, Whitehead PJ, Elwood PC. Fibrinogen, viscosity, and white blood cell count are major risk factors for ischemic heart disease. The Caerphilly' and Speedwell Collaborative Heart Disease Studies. Circulation 1991;83:836-44.

13 Elwood PC, Beswick AD, Sharp DS, Yarnell JWG, Rogers S, Renaud S. Whole blood impedance platelet aggregometry and ischemic heart disease. The Caerphilly Collaborative Heart Disease Study. Arteriosclerosis 1990;10:1032-6.

14 Elwood PC, Renaud S, Sharp DS, Beswick AD, O'Brien $J R$, Yarnell JWG. Ischemic heart disease and platelet aggregation. The Caerphilly Collaborative Heart Disease Study. Circulation $1991 ; 83: 38-44$.

15 Stout RW, Crawford V. Seasonal variations in fibrinogen concentrations among elderly people. Lancet 1991;338:9-13.

16 Kunes J, Tremblay J, Bellavance F, Hamet P. Influence of environmental temperature on the blood pressure of hypertensive patients in Montreal. Am $\mathcal{F}$ Hypertens 1991 4:422-6.

17 Tromp SW. Influence of weather and climate on the fibrinogen content of human blood. Int $\mathcal{f}$ Biometerol 1972;16:93.

18 Keatinge WR, Coleshaw SRK, Cotter F, Mattock K Murphy M, Chelliah R. Increases in platelet and red cell counts, blood viscosity, and arterial pressure during mild surface cooling: factors in mortality from coronary and cerebral thrombosis in winter. $B M F$ 1984;289. 1405-8.

19 Martin JF, Bath PMW, Burr ML. Influence of platelet size on outcome after myocardial infarction. Lancet 1991;338:1409-11.

20 Sharp DS, Beswick AD, O'Brien JR, Renaud S, Yarnell JWG, Elwood PC. The association of platelet and red cell count with platelet impedance changes in whole cllood and light-scattering changes in platelet rich blood and light-scattering changes in platelet rich plasma: evidence from the Caerphilly Collaborative

21 Ridker PM, Hennekens CH. Haemostatic risk factors for coronary heart disease. Circulation 1991;83:1098-100.

22 Yarnell JWG, Sweetnam PM, Rogers S, Elwood PC arnell JWG, Sweetnam PM, Rogers S, Elwood PC,
Bainton D, Baker IA, et al. Some long term effects of smoking on the haemostatic system: a report from the Caerphilly and Speedweff Collaborative Surveys. $f$ Clin Pathol 1987;40:909-13. 